\section{$\underset{\substack{\text { hommes } \\ \text { \& migrations }}}{ }$}

\section{Hommes \& migrations}

Revue française de référence sur les dynamiques

migratoires

1302 | 2013

Le Japon, pays d'immigration?

\title{
Alain Mabanckou, Lumières de Pointe-Noire
}

Paris, Seuil, 2013, 304 p., 19,50€

\section{Michaël Ferrier}

\section{OpenEdition \\ 1 Journals}

\section{Édition électronique}

URL : http://journals.openedition.org/hommesmigrations/2526

DOI : 10.4000/hommesmigrations.2526

ISSN : 2262-3353

\section{Éditeur}

Musée national de l'histoire de l'immigration

\section{Édition imprimée}

Date de publication : 1 avril 2013

Pagination : 190-191

ISBN : 978-2-919040-22-3

ISSN : 1142-852X

\section{Référence électronique}

Michaël Ferrier, « Alain Mabanckou, Lumières de Pointe-Noire », Hommes \& migrations [En ligne], 1302 |

2013, mis en ligne le 17 septembre 2013, consulté le 22 septembre 2020. URL : http://

journals.openedition.org/hommesmigrations/2526 ; DOI : https://doi.org/10.4000/

hommesmigrations.2526

Ce document a été généré automatiquement le 22 septembre 2020.

Tous droits réservés 


\section{Alain Mabanckou, Lumières de Pointe- Noire}

Paris, Seuil, 2013, 304 p., 19,50€

Michaël Ferrier

\section{RÉFÉRENCE}

Alain Mabanckou, Lumières de Pointe-Noire, Paris, Seuil, 2013, 304 p., 19,50€.

Lumières de Pointe-Noire nous conte un retour au pays natal, traversé de vertiges et d'une émotion d'autant plus forte qu'elle est contenue. Intelligemment, le livre s'ouvre sur une légende congolaise énigmatique : nous entrons d'emblée dans un monde différent, relié à la force mystérieuse des origines ainsi qu'à leur puissance parfois délétère. Un monde qu'on ne peut renier mais dont il faut savoir s'extraire.

2 Par instants, l'histoire tâtonne un peu, suivant en quelque sorte une démarche en crabe, de celles que le narrateur décrit lui-même dans une très belle page: "On croit qu'ils vont aller à gauche, ils font demi-tour, ils s'arrêtent sans savoir pourquoi, ils tournent en rond, et ils repartent en vitesse vers la droite avant de revenir à gauche. Mais ce que j'aime chez les crabes c'est qu'ils savent toujours où ils vont aller, et ils finissent par arriver tôt ou tard." Car, sous son allure de pèlerinage parfois chaotique, c'est un livre bien construit, scandé par des chapitres qui portent tous des titres de classiques du cinéma: le narrateur multiplie ainsi les travellings et les zooms sur une ville qu'il voit à travers le filtre de ses souvenirs, avec un zeste d'amertume. Il a sans doute aussi besoin de cet écran, à la fois pour retrouver cette ville et cette période de sa vie, mais aussi pour s'en détacher. Rencontres, voix, lumières, ambiances, retrouvailles quelquefois drôles, d'autres fois désenchantées, surmontées de l'ombre absente de la mère, qui ouvre le livre, et de celle de grand-mère Hélène, qui le clôt.

3 Régulièrement, des photographies viennent ponctuer le texte, comme si l'écriture renonçait à fouiller plus avant, comme si la réflexion s'arrêtait pour céder la place à un album de souvenirs couleur sépia, dont l'auteur ne sait finalement plus trop quoi faire. 
Alors s'ouvre un silence; une hésitation se glisse entre les points de suspension et les photographies : impuissant, le texte laisse la place à ces images simples, grignotées par le temps, "accablées par la poussière des regrets". Et d'une certaine manière, cela rend aussi ce livre très attachant. 